NIGHT PRAYER

I've been all over, here and there

And sleeping around.

On this mattress I lay me down.

I pray the pillow

To remember the cloud.

And if I awaken with her hair

Lying softly across my chest,

Let it be

The web I have spun to catch

The man left falling through my sleep.

\title{
Ross Talarico
}

\section{THINK OF MY DAUGHTER'S BIRTH}

It began you opened the glass door and stepped into the shower you forgot to take off your clothes and the water rose as easily as a squirrel goes down a tree where were you

It began you stepped into the shower everyone on the other side was watching and you expected that and grabbed for the soap quiet as moonrise when you stopped walking in a field as artificially waiting as the ticking of a car cooling saw the moonrise hang like a hummingbird outside the dark

It began you stepped into the shower and down to the book opening at the place of instructions stinging breathe they said breathe open your mouth open your eyes breathe 